This chapter examines the importance of college union facilities to create community and to enhance the role of college unions as the "living room of the campus."

\title{
College Unions, Learning, and Community Building
}

\author{
Loren J. Rullman, Kim D. Harrington
}

\begin{abstract}
We never educate directly, but indirectly by means of the environment. Whether we permit chance environments to do the work, or whether we design environments for the purpose makes a great difference.
\end{abstract}

(Dewey, 1916, p. 22)

This is a time of profound change in higher education, as concerns about the rising cost of higher education collide with the reality that large sums of money are spent on campus facilities, resulting in political optics that are challenging to explain to the general public (Blumenstyk, 2012). This explanation may be most challenging when expenditures include nonacademic facilities, such as college unions. In 2011, almost \$12 billion was spent on campus facilities with two thirds of it on new construction (Basu, 2011). The median price of a newly constructed college union facility was a sizable $\$ 21$ million (Abramson, 2011).

As a consequence, it is important that college unions are aligned explicitly with the academic mission of the institutions they support. If they are not so aligned, the mission of college unions is jeopardized. When constructed and managed with intentionality, college unions can make lasting and fundamentally important contributions to student learning and students' college experiences. While college unions are much more than facilities, the value of their physical structures to students' educational experiences is considerable. By examining the influence of architecture and the physical campus on student behavior, professionals in college unions can create physical environments for learning and facilitate a sense of belonging for students. 


\section{Architectural Theory and College Unions}

Before considering the impact of a college union's facility upon its users, it is important to consider more generally the influence of architecture itself on the environment. The impact of facilities upon how people feel, behave, and interact with each other has long been documented by contemporary authors (London, 2010; Tupper, Carson, Johnston, \& Mangat, 2008) who continue to apply John Dewey's (1916) belief about the importance of space to identity development and learning. Lewin (1936) suggested with his formula of $B=f(P, E)$ that behavior can be understood as a function of the interaction between the person and the environment. More specifically, the literature offers three essential perspectives about the influence of architecture: conceptualized as architectural determinism, architectural probabilism, and architectural possibilism (Devlin, 2010).

The premise of the first perspective, architectural determinism, is that human behavior is largely predictable and caused almost mechanistically by the physical environment. This perspective suggests that the placement of furniture, walls, doors, and other artifacts will cause recurring and consistent responses by facility users. For example, based on the placement of these structures, people will exit a lounge in consistently predictable ways. The second perspective, architectural probabilism, suggests that behavior is not entirely predictable and that the probability of behavior responses can be enhanced with thoughtful facility design. For example, a student lounge that is well lit, nicely furnished, and easy to find may increase the likelihood of use. The third perspective, architectural possibilism, assumes a predetermined response is unlikely and that all physical features have an equal opportunity to affect the user experience. Devlin (2010) summarized these three perspectives simply as follows: "determinism suggests the design created the outcome; probabilism suggests the design makes a certain outcome more likely, and possibilism suggests the environment creates the opportunity for an outcome" (p. 119).

To those working in the college union field, these perspectives are helpful, but insufficient, to fully explain human behavior given the vast complexities of social and psychological differences found on most campuses. This is especially true given the diversity of people that, by definition and intention, inhabit college union environments (Alleman, Holly, \& Costello, 2012; Banning \& Cunard, 1996; Strange \& Banning, 2001). Indeed, as Cuyjet, Howard-Hamilton, and Cooper (2011) reported, because of the inadequacy of architecture alone to explain what occurs inside a facility, "it becomes necessary to examine the impact of the environment in smaller, more focused, less general terms to observe how the same element of the environment can have different-sometimes minutely, sometimes drasticallyeffects on the inhabitants of the community" (p. 37). Cuyjet et al. explained that the degree of homogeneity within a population, and the characteristics of dominant populations relative to subpopulations, can affect the impact 
of the human aggregate upon a particular environment. That is, the cultural conditioning that people bring to a campus affects the ways they experience the architecture of that campus. For example, the individualism of American culture may result in greater distance between lounge seating than is characteristic of other cultures, which are more comfortable with collective and social interaction. Or, a historically accurate display of the college union organization's White male founders may be deemed reverential by some, but insensitive by those with deep interest in issues of inclusion. In sum, the relationship between a space and its users is not solely a product of the architecture, yet the physical framework of a campus and the design of its facilities play a role in human experiences.

\section{College Union Facilities' Impacts on Students}

The physical campus as an entity conveys intended and unintended messages to students, employees, and visitors. The cleanliness and manicure of the campus, the condition of the facilities, the location of needed services, and the availability of open space all send messages or "non-verbal cues" about what the institutional values (Strange \& Banning, 2001, p. 16). If, for example, an institution imagines itself as highly accessible, with low barriers to student success, and deeply focused on student support, then placement of its admissions, financial aid, advising, and child care services at the edge of campus rather than at its core, or in low quality or unkempt spaces, may convey incongruence between what it values and what it does. On the other hand, an institutional culture that believes learning is derived from frequent student engagement with peers, active and self-directed cocurricular involvement, and regular exposure to diverse perspectives may illustrate these values by locating its student organization offices, its collaborative spaces, and its multicultural programming along primary campus pathways and in highly visible locations. Since college union facilities often host offices and opportunities for student engagement and cocurricular involvement, their location and condition send nonverbal messages as Strange and Banning's (2001) research showed. Physical structures are the means by which the institution communicates nonverbally to its users about its values, vision, and capabilities.

Although no university with a physical campus can easily exist without formal instruction space, it is often "the informal territory of collegiate life between these important [academic] settings that can have the most impact" (Atkins \& Oakland, 2008, "Useful applications," para. 1). Kuh, Schuh, and Whitt (1991) suggested that nonacademic spaces are important because "interaction among community members is fostered by the availability of indoor and outdoor spaces where people can come together without much effort. Institutions should consider whether their campuses have adequate places that encourage spontaneous, informal interactions among 
students" (p. 309). Student-focused spaces, like the Union Terrace at the University of Wisconsin, serve as emblems of the institution's core values, as literal and symbolic bridges between faculty and students, and as physical vehicles for teaching institutional traditions (Atkins \& Oakland, 2008).

Increasingly, higher education leaders recognize the value of campus spaces that are flexible, can enhance collaboration, and provide greater access to technology (Beichner et al., 2007; Massis, 2010). Jamieson (2003), for example, asserted that universities "need spaces designed to generate interaction, collaboration, physical movement, and social engagement as primary elements of the student learning experience" (p. 121). Professionals in college unions purposefully engineer experiences for students to interact with others. As such, college union facilities designed for this purpose are well situated for the learning Jamieson (2003) described. Indeed, the physical campus is "both functional and symbolic" (Strange \& Banning, 2001, p. 15), and the college union is uniquely important to both.

College union facilities influence community, learning, and engagement due to the social implications of space or what Strange and Banning (2001) referred to as proxemics. For example, the overt and covert messages sent by seating arrangements, cleanliness, signage, types of offices, and accessibility all influence human feelings, behavior, interaction, engagement, energy level, attitude, and even how much time individuals will spend in a facility. Spaces can signal feelings of control or emancipation, interaction or isolation, acceptance or rejection, community or invisibility (Tupper et al., 2008). In fact, one study found that behaviors of people can be more accurately understood by the settings they are in than from the individual characteristics of the inhabitants themselves (Kenney, Dumont, \& Kenney, 2005). As noted previously, Cuyjet et al. (2011) discussed that physical artifacts can evoke nonverbal responses that can be negative or positive, and are either aligned or misaligned with institutional intention. Further, interpretation is always culturally understood or received within an individual's cultural context. For example, an architecturally imposing college union sends a signal to students about the importance of cocurricular life, or a women's center in the basement of a peripheral facility sends a message about the centrality of women's concerns. Moreover, when verbal (e.g., women's concerns are important) and nonverbal (e.g., a peripheral location for the women's center) messages are received, the nonverbal communication is typically more believable (Cuyjet et al., 2011; Strange \& Banning, 2001).

Psychosocial and behavioral responses are positively influenced by a myriad of facility elements, including the existence of and ease of movement between spaces for prospect (visual access to other people) and refuge (feeling safe and protected); natural daylight and artifacts; sensory variability; occupant sense of agency or ownership; flexibility of space and furnishings; opportunities for spontaneous social encounters; moderate sound levels; presence of social equity and respect between people; food and other stimuli for ritual and relationship building; and purposeful mixing of offices, 
services, programs, and spaces that invite and retain the campus community (i.e., academic support, meeting and study spaces, student life programs, private and social lounges, essential student services, welcoming areas, student organization, and involvement spaces; Atkins \& Oakland, 2008; Heerwagen, 2008; Rullman \& van den Kieboom, 2012).

\section{College Union Facilities as Places for Learning}

The quality and quantity of student engagement in both the academic and cocurricular aspects of a college environment enhance learning and skill development (Pascarella \& Terenzini, 2005). The literature is replete with evidence that a relationship exists between student learning and student involvement and that campus community including physical design has an impact on student learning, academic persistence, and student retention (Astin, 1993; Kuh, Cruce, Shoup, Kinzie, \& Gonyea, 2008; Kuh et al., 1991; Palmer, Maramba, \& Elon Dancy, 2011; Strange \& Banning, 2001; Tinto, 1987; Tinto, Goodsell-Love, \& Russo, 1993). Conditions that contribute to campus community include, for example, meaningful faculty-student interaction (NASPA, 2010; Zhao \& Kuh, 2004), participation in educationally purposeful activities (Kinzie \& Schuh, 2008; Palmer et al., 2011), student involvement in cocurricular and social aspects of college life (Cheng, 2004; Elkins, Forrester, \& Noel-Elkins, 2011), and availability of quality services to support diverse student needs (Nasir \& Al-Amin, 2006).

Bickford and Wright (2006) described the catalyzing role that community has upon learning and how community-based learning causes "members [to] interact in a meaningful way that deepens their understanding of each other and leads to learning" (p. 4.2). That is, interaction and dialogue with others causes reflection, introspection, values clarification, and a sense of self, with both private interests and concomitant responsibilities to others (London, 2010). Community created in college unions can help individuals apply what is learned in and beyond the classroom, while also experimenting with meaningful interaction and a deepening of understanding about self and others. College unions provide such opportunities through, for example, programming boards and student organizations that plan lectures, cultural activities, and social events in college unions to educate and challenge other students, while simultaneously offering powerful learning experiences for the students who comprise these boards and organizations (Joint Task Force on Student Learning, 1998).

Places are physical domains where interactions between individuals and groups generate social meaning (Marcouyeux \& Fleury-Bahi, 2011). Since learning and community building are optimally social processes that develop meaning making, highlight memories, and create institutional stories (Broussard, 2009), it is critical that a college union's spaces provide intentional opportunities for meaningful interactions with peers, staff, and faculty, who are critical to quality learning experiences (Kuh, Kinzie, Schuh, 
Whitt, \& Associates, 2010). To that end, college unions are ideal physical environments for all members of the institutional family to be welcomed into meaningful interaction and relationship building, and for learning to be of the highest quality.

\section{College Union Facilities as Places for Belonging}

College unions can be places for individual students to feel part of a larger community of learners. If learning is social, and a sense of community is vital to the learning process, then students need to feel a part of the community to take full advantage of all possible learning experiences. As this volume describes elsewhere, college unions have a unique role to play in cultivating feelings of belonging and affinity to the institution and in serving individual student needs. As a result of participating in programs and activities housed in college unions, a majority of students feel a part of the campus community (NASPA, 2010). Schlossberg's (1989) marginality and mattering research explained that students who engage in the campus community experience a sense of mattering, that is they feel included and cared for by others in the community. On the other hand, students who do not feel like they matter to others experience marginality, which is characterized by feelings of isolation and exclusion. Students who feel marginalized are unlikely to participate fully in college life. Chronic feelings of marginality can harm a student's physical and psychological health, self-efficacy, and overall academic success and retention.

Because a college union, by definition, "honors each individual and values diversity" (Association of College Unions International, 1996, para. 5), the intention developed around the construction of a college union facility may contain services, support, programs, and offices designed to mitigate feelings of isolation and enhance feelings of belonging. In this way, a college union conveys that the institution is responsive to student needs and invites students into a community with others who care about them while offering myriad opportunities for learning and engagement (Strange \& Banning, 2001).

\section{Future Considerations}

Although this chapter addressed primarily the importance of a college union facility to student learning, engagement, and the overall sense of community, college union professionals increasingly must be cognizant of many other issues and trends. These include, for example, sustainable construction and operations (Radoff, 2011); economic pressures and privatization of institutional services (Russell, 2010); safety management and emergency operations (NACUBO, 2009); and, as noted elsewhere, technological changes which affect operations and services found in college unions. Each of these topics is beyond the scope of this chapter, but are worthy of further 
exploration in their own right and serve as examples of the multifaceted role that a college union plays for institutions of higher education.

\section{Conclusion}

As a result of what is known about the influence of involvement and community on learning, about the importance of facility design on human behavior, and about the role of a college union in achieving the institution's objectives, it is imperative that college union facilities be designed and managed with intended outcomes in mind and with flexibility to be responsive over time. College union facilities do not have a uniform template. Individual college union facilities should take into account the campus' physical framework and the symbolism of its location in context of campus and local demographics. Furthermore, the nature and needs of the campus population, the appropriate mix of what is contained within its walls, and the understanding of proxemics should be considered in its design.

\section{References}

Abramson, P. (2011). The 2011 college construction report. Retrieved from http://www.peterli.com/cpm/pdfs/CollegeConstructionReport2011.pdf

Alleman, N., Holly, L. N., \& Costello, C. A. (2012). Agency and influence: The organizational impact of a new school of education building. Planning for Higher Education, $41(2), 1-10$.

Association of College Unions International. (1996). Role of the college union. Retrieved from http://www.acui.org/content.aspx?menu_id=30\&id=296

Astin, A. (1993). What matters in college? San Francisco, CA: Jossey-Bass.

Atkins, J., \& Oakland, D. (2008). College unions transform campus life at small regional institutions. The Bulletin, 76(3). Retrieved from http://www.acui.org /publications/bulletin/article.aspx?issue $=700 \& i d=6954$

Banning, J., \& Cunard, M. (1996). An ecological perspective of buildings and behavior: Implications for the renovation and construction of the college union. College Services Administration, 19(4), 38-41.

Basu, A. (2011). Higher education construction spending: Peak, slump, recover? Retrieved from http://www.constructionexec.com/Issues/June_2011/Economic_Outlook.aspx

Beichner, R., Saul, J., Abbott, D., Morse, J., Deardorff, D., Allain, R., ... Risely, J. (2007). The Student Centered Activities for Large Enrollment Undergraduate Programs (SCALEUP) Project. Retrieved from http://www.per-central.org/items/detail.cfm?ID $=4517$

Bickford, D., \& Wright, D. (2006). Community: The hidden context of learning. In D. G. Oblinger (Ed.), Learning spaces. Boulder, CO: EDUCAUSE. Retrieved from http://net.educause.edu/ir/library/pdf/PUB7102d.pdf

Blumenstyk, G. (2012). College officials welcome Obama's focus on higher-education costs, but raise some concerns. The Chronicle of Higher Education. Retrieved from http://chronicle.com/article/President-Puts-College-Costs/130503/

Broussard, E. (2009, May 1). The power of place on campus. The Chronicle of Higher Education. Retrieved from http://chronicle.com/article/The-Power-of -Place-on-Campus/3399

Cheng, D. (2004). Students' sense of campus community: What it means, and what to do about it. NASPA Journal, 41(2), 216-234. 
Cuyjet, M., Howard-Hamilton, M., \& Cooper, D. (2011). Multiculturalism on campus: Theory, models, and practices for understanding diversity and creating inclusion. Sterling, VA: Stylus.

Devlin, A. (2010). What Americans build and why: Psychological perspectives. Cambridge, MA: Cambridge University Press.

Dewey, J. (1916). Democracy and education: An introduction to the philosophy of education. New York, NY: Macmillian.

Elkins, D. J., Forrester, S. A., \& Noel-Elkins, A. V. (2011). Students' perceived sense of campus community: The influence of out of class experiences. College Student Journal, 45(1), 105-121.

Heerwagen, J. (2008). Psychosocial value of space. Retrieved from http://www .wbdg.org/resources/psychspace_value.php

Jamieson, P. (2003). Designing more effective on campus teaching and learning spaces: A role for academic developers. International Journal for Academic Development, 8(1-2), 119-133.

Joint Task Force on Student Learning. (1998, June). Powerful partnerships: A shared responsibility for learning. Retrieved from http://www.nova.edu/cwis /saase/forms/powerful_partnerships.pdf

Kenney, D., Dumont, R., \& Kenney, G. (2005). Mission learning and community through campus design. Westport, CT: Praeger Publishers.

Kinzie, J., \& Schuh, J. H. (2008). DEEP (documenting effective educational practice) colleges and universities as communities. NASPA Journal, 45(3), 406-424.

Kuh, G. D., Cruce, T., Shoup, R., Kinzie, J., \& Gonyea, R. (2008). Unmasking the effects of student engagement on first year college grades and persistence. The Journal of Higher Education, 79(5), 540-563.

Kuh, G. D., Kinzie, J., Schuh, J., Whitt, E., \& Associates. (2010). Student success in college. San Francisco, CA: Jossey-Bass.

Kuh, G. D., Schuh, J., \& Whitt, E. (1991). Involving colleges. Successful approaches to fostering student learning and development outside the classroom. San Francisco, CA: Jossey-Bass.

Lewin, K. (1936). Principles of topological psychology. New York, NY: McGraw-Hill.

London, D. (2010). Building the great community: John Dewey and the public spaces of social democracy. Retrieved from http://www.academia.edu /934760/Building_the_Great_Community_John_Dewey_and_ThePublic_Spaces_of _Social_Democracy

Marcouyeux, A., \& Fleury-Bahi, G. (2011). Place-identity in a school setting: Effects of the place image. Environment and Behavior, 43(3), 344-362.

Massis, B. (2010). The academic library becomes the academic learning commons. New Library World, 111(3/4), 161-163.

Nasir, N., \& Al-Amin, J. (2006). Creating identity safe spaces on college campuses for Muslim students. Change, 38(2), 22-27.

NASPA. (2010). Senior student affairs officer: 2010 executive report. Washington, DC: Author.

National Association of College and University Business Officers (NACUBO). (2009). Results of the national campus safety and security project survey. Retrieved from http://www.nacubo.org/Documents/Initiatives/CSSPSurveyResults.pdf

Palmer, R. T., Maramba, D. C., \& Elon Dancy, T., II. (2011). A qualitative investigation of factors promoting the retention and persistence of students of color in stem. The Journal of Negro Education, 80(4), 491-504.

Pascarella, E., \& Terenzini, P. (2005). How college affects students: Vol. 2. A decade of research. San Francisco, CA: Wiley. 
Radoff, J. (2011). Higher education-The vibrant epicenter of a sustainable future. Retrieved from http://www.torkusa.com/Global/6_North_America/White\%20Papers /Higher_Education_2011_White_Paper\%2009-20-11\%20FINAL\%20_2_.pdf

Rullman, L., \& van den Kieboom, J. (2012). Creating community: Designing spaces that make a difference. Planning for Higher Education, 41(1), 1-16.

Russell, A. (2010). Outsourcing instruction: Issues for public colleges and universities. American Association of State Colleges and Universities. Retrieved from http://www.aascu.org/policy/publications/policy-matters/2010/outsourcing.pdf

Schlossberg, N. K. (1989). Marginality and mattering: Key issues in building community. In D. C. Roberts (Ed.), New Directions for Student Services: No. 48. Designing campus activities to foster a sense of community (pp. 5-15). San Francisco, CA: Jossey-Bass.

Strange, C., \& Banning, J. (2001). Educating by design: Creating campus learning environments that work. San Francisco, CA: Jossey-Bass.

Tinto, V. (1987, November). Principles of effective retention. Speech presented at the Maryland College Personnel Association Conference, Largo, MD.

Tinto, V., Goodsell-Love, A., \& Russo, P. (1993). Building community. Liberal Education, 79(4), 16-21.

Tupper, J. A., Carson, T., Johnston, I., \& Mangat, J. (2008). Building place: Students' negotiation of spaces and citizenship in schools. Canadian Journal of Education, 31(4), 1065-1092.

Zhao, C. M., \& Kuh, G. D. (2004). Adding value: Learning communities and student engagement. Research in Higher Education, 45(2), 115-138.

LOREN J. RULLMAN is an associate vice president for Student Affairs at the University of Michigan. He serves as ACUI representative on the Board of Directors of the Council for the Advancement of Standards in Higher Education.

Kim D. Harrington is the director of the Student Center at the Georgia Institute of Technology and currently serves as president-elect of the Association of College Unions International. 